\title{
Exopolysaccharide Matrix of Developed Candida albicans Biofilms After Exposure to Antifungal Agents
}

\author{
Wander José da SILVA ${ }^{1}$ \\ Letícia Machado GONÇALVES ${ }^{1}$ \\ Jayampath SENEVIRATNE ${ }^{2}$ \\ Nipuna PARAHITIYAWA ${ }^{3}$ \\ Lakshman Perera SAMARANAYAKE ${ }^{2}$ \\ Altair Antoninha DEL BEL CURY ${ }^{1}$ \\ ${ }^{1}$ Department of Prosthodontics and Periodontology, Piracicaba Dental School, \\ UNICAMP - University of Campinas, Piracicaba, SP, Brazil \\ ${ }^{2}$ Oral Biosciences, Faculty of Dentistry, The University of Hong Kong, Pokfulam, Hong Kong, China \\ ${ }^{3}$ Faculty of Medicine, University of Peradeniya, Colombo, Sri Lanka
}

\begin{abstract}
This study aimed to evaluate the effects of fluconazole or nystatin exposure on developed Candida albicans biofilms regarding their exopolysaccharide matrix. The minimal inhibitory concentration (MIC) against fluconazole or nystatin was determined for C. albicans reference strain (ATCC 90028). Poly(methlymethacrylate) resin (PMMA) specimens were fabricated according to the manufacturer's instructions and had their surface roughness measured. Biofilms were developed on specimens surfaces for $48 \mathrm{~h}$ and after that were exposed during $24 \mathrm{~h}$ to fluconazole or nystatin prepared in a medium at MIC, $10 \mathrm{x}$ MIC or $100 \mathrm{x}$ MIC. Metabolic activity was evaluated using an XTT assay. Production of soluble and insoluble exopolysaccharide and intracellular polysaccharides was evaluated by the phenol-sulfuric method. Confocal laser scanning microscope was used to evaluate biofilm architecture and percentage of dead/live cells. Data were analyzed statistically by ANOVA and Tukey's test at 5\% significance level. The presence of fluconazole or nystatin at concentrations higher than MIC results in a great reduction of metabolic activity $(\mathrm{p}<0.001)$. At MIC or $10 \mathrm{x}$ MIC, fluconazole showed high amounts of intracellular polysaccharides $(p<0.05)$, but did not affect the exopolysaccharide matrix ( $>0.05)$. The exposure to nystatin also did not alter the exopolysaccharide matrix at all the tested concentrations $(\mathrm{p}>0.05)$. Biofilm architecture was not affected by either of the antifungal agents $(p>0.05)$. Nystatin promoted higher proportion of dead cells $(p<0.05)$. It may be concluded that fluconazole and nystatin above the MIC concentration reduced the metabolic activity of $C$. albicans biofilms; however, they were not able to alter the exopolysaccharide matrix and biofilm architecture.
\end{abstract}

Key Words: antifungal agents, Candida albicans, biofilm, denture bases.

\section{INTRODUCTION}

A large percentage of denture wearers are affected by Candida-associated denture stomatitis (CADS), with C. albicans identified as the main pathogen of this condition (1). One of the factors contributing to the virulence of $C$. albicans is its ability to attach to biotic and/or abiotic surfaces and growing in communities known as biofilms (2). These structured communities, encased in a matrix of exopolysaccharide, display unique characteristics that confer survival advantages over their planktonic counterparts $(3,4)$.

It is known that there are many ecologic advantages in forming biofilms, including protection from the environment, resistance to physical and chemical stress, nutrient availability and metabolic cooperation (5). Additionally, from the perspective of infection, the most important feature of biofilm growth is its high resistance to antifungal agents, which can be up to 100 -fold greater than that of planktonic cells (4-7). The mechanisms contributing to this increased antifungal resistance are not well established, although

Correspondence: Profa. Dra. Altair Antoninha Del Bel Cury, Departamento de Prótese e Periodontia, Faculdade de Odontologia de Piracicaba, UNICAMP, Avenida Limeira, 901, 13414-903 Piracicaba, SP, Brasil. Tel: +55-19-2106-5294. Fax: +55-19-2106-5211. e-mail: altcury@fop.unicamp.br 
several possibilities have been investigated. These possibilities include a lower metabolic rate of cells within biofilms (8), presence of an exopolysaccharide matrix (9-11), persistent cells (3) and biofilm three-dimensional conformation (12).

The antifungal agents most commonly used to treat patients with CADS are azoles or polyenes $(8,9)$ and the mechanism of actions of these antifungal agents is directly related to alterations of the biofilm's metabolic and structural levels (5-7). The azoles, such as fluconazole, act as a fungistatic agent affecting the ergosterol biosynthesis and, consequently, the fungal cell permeability (7). In contrast, the polyenes, which include nystatin, are fungicidal agents and cause fungal cell death interfering in ergosterol-containing membranes and also by oxidative damage (9).

Considering the mechanism of action of fluconazole (7), it would be natural to expect that after the exposure to fluconazole, developed biofilms could maintain their architecture, but probably with particular changes in cell metabolism. Likewise, it is expected the complete disruption of developed biofilms after administrating nystatin (9).

Additionally, considering that the antifungal dose required for biofilm eradication usually exceeds the minimal inhibitory concentration (MIC) recommended for eradication of its planktonic counterparts $(5,6)$, it is expected that concentrations higher than MIC could be another point affecting the biofilm architecture. So far, however, it is not fully understood whether antifungal agents at concentrations higher than MIC could actually interfere on biofilms at metabolic levels and/or biofilm organization, particularly in the exopolysaccharide matrix. Therefore, the aim of this study was to evaluate the exopolysaccharide matrix of developed C. albicans biofilms after exposure to fluconazole or nystatin.

\section{MATERIAL AND METHODS}

\section{Experimental Design}

This in vitro study had a randomized and blinded design. MIC was determined for C. albicans reference strain (ATCC 90028) against fluconazole or nystatin. Poly(methlymethacrylate) (PMMA) resin discs $(10 \mathrm{~mm} \times 2 \mathrm{~mm}$ ) were fabricated according to the manufacturer's directions and had their surface roughness measured. Biofilms of $C$. albicans were allowed developing on specimen surface for $48 \mathrm{~h}$. Next, the biofilms were exposed during $24 \mathrm{~h}$ to fluconazole or nystatin prepared in a medium at MIC, $10 \mathrm{x}$ MIC or 100 $x$ MIC. Metabolic activity was evaluated using an XTT colorimetric assay. Production of exopolysaccharide and intracellular polysaccharides were evaluated using the phenol-sulfuric method. Confocal laser scanning microscopy was used for architecture analysis and percentage of dead/live cells. Statistical analysis was performed considering as study factors the antifungal agent and its concentrations.

\section{Specimen Preparation}

Discs of water bath PMMA resin (Lucitone 550; Denstply, Rio de Janeiro, RJ, Brazil) were fabricated in accordance with the manufacturer's directions. Next, the specimens were ground using progressively smoother aluminum oxide papers $(320,400$ and 600 grits) in a horizontal polisher (model APL-4; Arotec, São Paulo, SP, Brazil) and immersed in purified water for $12 \mathrm{~h}$ at $35^{\circ} \mathrm{C}$ for residual monomer release (13).

The surface roughness of specimens was measured using a profilometer (Surfcorder SE 1700; Kosaka Laboratory Ltd, Kosaka, Japan) with a 0.01 $\mu \mathrm{m}$ precision, calibrated at sample length of $0.8 \mathrm{~mm}$, $3.2 \mathrm{~mm}$ percussion of measure and $0.5 \mathrm{~mm} / \mathrm{s}$. Three readings were made for each specimen and a mean value was calculated. The average surface roughness obtained was $0.32 \pm 0.05 \mu \mathrm{m}$. After that, the specimens were disinfected with $70 \%$ alcohol, ultrasonicated for 20 min to remove any residues, and randomly assigned to groups according to antifungal agent and their respective concentrations.

\section{C. albicans Suspensions}

C. albicans reference strain (ATCC 90028) was aerobically cultured on Sabouraud Dextrose Agar (Difco Laboratories, Detroit, MI, USA) at $35^{\circ} \mathrm{C}$ for $24 \mathrm{~h}$. A loopful of the growth was inoculated into Yeast Nitrogen Base broth (YNB; Difco Laboratories) supplemented with $50 \mathrm{mM}$ glucose and incubated for $18 \mathrm{~h}$ at $35^{\circ} \mathrm{C}$ in an orbital shaker (model NT 151; Kline Shaker, Nova Técnica Laboratory, São Paulo, SP, Brazil).

Thereafter, cells were harvested and washed twice with phosphate buffered saline (PBS; pH 7.2), suspended in YNB supplemented with $100 \mathrm{mM}$ glucose and optically adjusted to a density of approximately $10^{7}$ cells $/ \mathrm{mL}$. 


\section{Minimal Inhibitory Concentration (MIC)}

MIC of fluconazole (reference powder; SigmaAldrich Co., St. Louis, MO, USA) or nystatin (reference powder; Sigma-Aldrich) against $C$. albicans was determined based on M27-A3 standards (14). Tests were performed in triplicate, on three different occasions.

\section{Biofilm Development}

Discs were placed inside sterilized 24-well plates and $2 \mathrm{~mL}$ of $C$. albicans suspensions were added. This set was incubated for $90 \mathrm{~min}$ at $35^{\circ} \mathrm{C}$ in an orbital shaker. After the adhesion phase, specimens were washed twice with PBS and exposed to YNB supplemented with $100 \mathrm{mM}$ glucose for $48 \mathrm{~h}$ of biofilm development. The specimens were washed with PBS and the medium was changed every $24 \mathrm{~h}$. After that, medium containing fluconazole or nystatin was prepared in YNB supplemented with $100 \mathrm{mM}$ glucose at MIC, 10 $\mathrm{x}$ MIC or $100 \mathrm{x}$ MIC. Plates were incubated for $24 \mathrm{~h}$ at $35^{\circ} \mathrm{C}$ in an orbital shaker. After exposure, biofilms were evaluated for their metabolic activity, polysaccharide production and architecture. All tests were performed in four replicates, on three different occasions.

\section{Metabolic Activity}

The metabolic activity was measured using an adapted XTT assay (15). Briefly, XTT (Sigma-Aldrich) was dissolved in PBS supplemented with $200 \mathrm{mM}$ of glucose $(1.0 \mathrm{mg} / \mathrm{mL})$ and mixed to a menadione solution $(0.4 \mathrm{mM})$. The developed biofilms exposed to fluconazole or nystatin were washed twice and transferred to new plates containing the XTT solution. This set was protected from light and incubated at $35^{\circ} \mathrm{C}$ for $3 \mathrm{~h}$. The solution of each well was centrifuged and the supernatant was transferred to a 96-well plate. The colorimetric changes were measured at $492 \mathrm{~nm}$ using a plate reader (Spectra-MAX 340; Molecular Devices Ltd., Sunnyvale, CA, USA).

\section{Polysaccharide Extraction}

For polysaccharide extraction, the developed biofilms exposed to fluconazole or nystatin were washed twice and transferred to plastic tubes containing PBS. This set was sonicated at $7 \mathrm{~W}$ for $30 \mathrm{~s}$. An aliquot of this solution was centrifuged $\left(10,000 \mathrm{~g}\right.$ for $5 \mathrm{~min}$ at $\left.4^{\circ} \mathrm{C}\right)$ and the supernatant containing exopolysaccharide soluble (EPS) was transferred to another tube named EPS. To the pellet, an aliquot of $1 \mathrm{M} \mathrm{NaOH}$ was added for the exopolysaccharide insoluble (EPI) extraction. The tube was agitated for $15 \mathrm{~min}$, centrifuged and the supernatant was transferred to another tube named EPI. Finally, an aliquot of $1 \mathrm{M} \mathrm{NaOH}$ was added to the residual pellet for the intracellular polysaccharide (IP) extraction (16). The tube was heated for $15 \mathrm{~min}$ at $100^{\circ} \mathrm{C}$, centrifuged and the supernatant was transferred to another tube named IP. To the tubes EPS, EPI and IP, 3 volumes of cold ethanol were added and maintained for $30 \mathrm{~min}$ at $-20^{\circ} \mathrm{C}$. Next, the tubes were centrifuged and pellets were washed twice with cold $75 \%$ ethanol. Precipitated polysaccharides were resuspended in $1 \mathrm{M} \mathrm{NaOH}$ and total carbohydrate was estimated by the phenol sulfuric method (17), using glucose as standard. Results were normalized to the dry weight of biofilm.

\section{Biofilm Architecture}

For architecture analysis, the developed biofilms exposed to fluconazole or nystatin were stained using SYTO-9 and propidium iodide (Live/Dead BacLight viability kit; Molecular Probes, Eugene, OR, USA) and incubated during $20 \mathrm{~min}$ protected from light at $35^{\circ} \mathrm{C}$. Images of stained biofilms were captured using a confocal scanning laser microscopy (CSLM; Leica Microsystems CMS, Mannheim, Germany). A series of images were obtained at $1-\mu \mathrm{m}$ intervals. At least five representative optical fields were captured for each specimen. COMSTAT software was used to analyze the bio-volume $\left(\mu \mathrm{m}^{3} / \mu \mathrm{m}^{2}\right)$, average thickness $(\mu \mathrm{m})$, diffusion distance $(\mu \mathrm{m})$ and dead/live cells ratio (\%) (18).

\section{Statistical Analysis}

All analyses were performed using the SAS software (SAS Institute Inc., version 9.0; Cary, NC, USA) with the level of significance set at $5 \%$. The normality of error distribution and the degree of nonconstant variance were checked for each response variable using the SAS/LAB package and data were transformed as suggested by the software: metabolic activity, EPS, EPI and IP $(\log 10)$, bio-volume and average thickness (square root) and roughness coefficient (exponentiation, $\mathrm{y}^{2}$ ). All data were analyzed using twoway ANOVA, considering as study factors the antifungal agent and its concentrations. 


\section{RESULTS}

MIC values obtained for fluconazole and nystatin were $0.5 \mu \mathrm{g} / \mathrm{mL}$ and $2.0 \mu \mathrm{g} / \mathrm{mL}$, respectively. A significant reduction in metabolic activity was observed for $C$. albicans biofilms developed in the presence of fluconazole or nystatin at concentrations higher than MIC $(p<0.05)$. However, no statistically significant differences were observed between $10 \mathrm{x}$ MIC or $100 \mathrm{x}$ MIC for fluconazole $(p>0.05)$. The great reduction was found for biofilms in the presence of nystatin, decreasing $80 \%$ at $10 \times$ MIC and $95 \%$ at $100 \times$ MIC (Fig. 1).

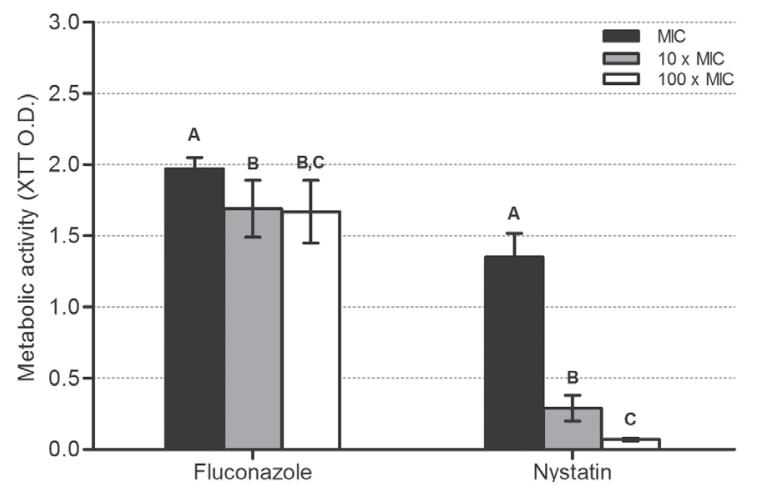

Figure 1. Metabolic activity for C. albicans biofilms developed on PMMA surface in the presence of fluconazole or nystatin at MIC, $10 \times$ MIC or 100 x MIC concentrations. Different letters indicate that are significant differences between fluconazole or nystatin tested concentrations $(\mathrm{p}<0.05)$.

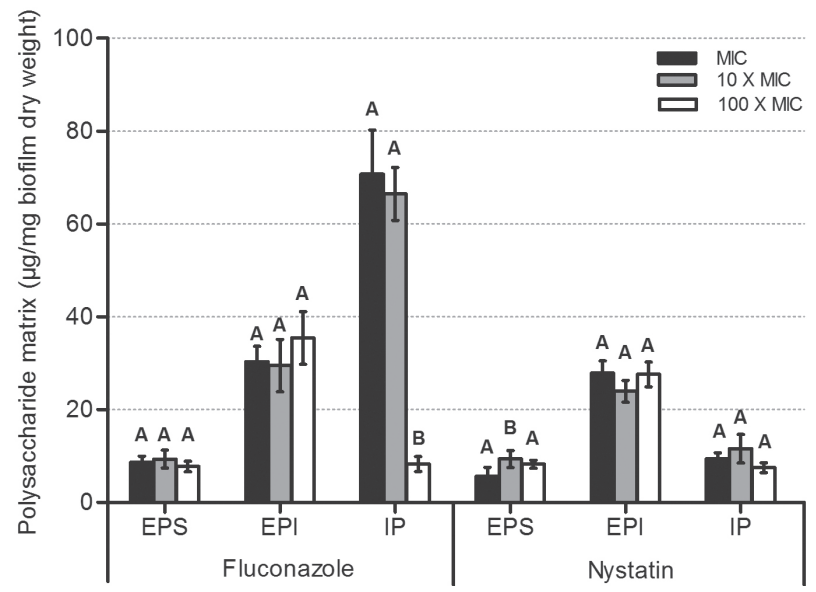

Figure 2. Polysaccharide matrix ( $\mu \mathrm{g} / \mathrm{mg}$ biofilm dry weight) for C. albicans biofilms developed on PMMA surface in the presence of fluconazole or nystatin at MIC, 10 x MIC or $100 \times$ MIC concentrations. Different letters indicate significant differences between fluconazole or nystatin tested concentrations $(p<0.05)$.
The amount of EPS and EPI from biofilm matrix was not affected by the presence of fluconazole at all concentrations ( $p>0.05)$. Still for this antifungal, high amounts of IP at MIC and $10 \mathrm{x}$ MIC were found. For nystatin, there were no differences for EPI and IP amounts at all investigated concentrations $(\mathrm{p}>0.05$, Fig. 2).

The architecture of $C$. albicans biofilms was not affected by the presence of fluconazole or nystatin at all evaluated concentrations ( $p>0.05)$, as shown by the parameters of bio-volume, average thickness and diffusion distance. In contrast, dead/live cells ratio was significantly higher for fluconazole at $100 \mathrm{x}$ MIC $(\mathrm{p}<0.05)$, and for nystatin at $10 \mathrm{x}$ MIC and $100 \times \mathrm{MIC}$ $(p<0.05$, Fig. 3$)$ relative to the other concentrations.

In CLSM images, the live cells appear as green, while the dead cells appear as red. In the z-slices of $C$. albicans biofilms was observed a great amount of black spaces between cells in the presence of fluconazole at $10 \mathrm{x}$ MIC and $100 \times$ MIC (Fig. 4). Additionally, it was possible to identify higher amounts of hyphae forms at MIC concentration (Fig. 4A) and dead cells at $100 \times$ MIC (Fig. 4C). For nystatin, was observed a more compact biofilm, with smaller black spaces and large amount of dead cells at all concentrations (Figs. 4D-4F).

\section{DISCUSSION}

Considering the mechanism of action of

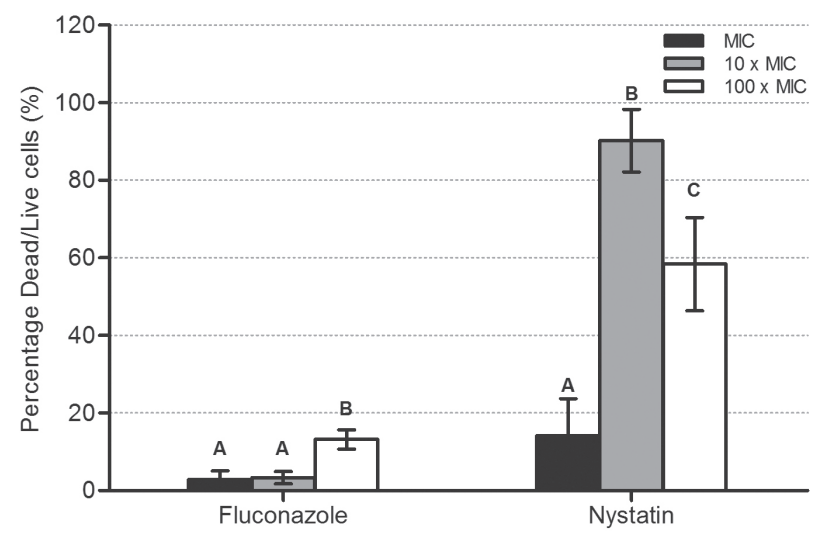

Figure 3. Dead/live cells ratio (\%) for C. albicans biofilms developed on PMMA surface in the presence of fluconazole or nystatin at MIC, 10 x MIC or 100 x MIC concentrations. Different letters indicate significant differences between fluconazole or nystatin tested concentrations $(\mathrm{p}<0.05)$. 
fluconazole and nystatin, it is expected particular changes in the cellular metabolism and architecture after their exposure to developed C. albicans biofilm. Also, it is known that the antifungal dose required for biofilm eradication usually exceeds the MIC $(5,6)$. However, it is not fully evaluated yet if fluconazole or nystatin at concentrations higher than MIC could actually interfere on biofilm at metabolic levels, exopolysaccharide production and/or biofilm organization. Thus, the obtained results suggest a global understanding about biofilm behavior when exposed to antifungal agents commonly used in clinical practice.

The administrated concentration and availability of fluconazole or nystatin in oral cavity is an important factor that should be considered in the treatment of CADS $(8,9)$. It is known that after swallowing a suspension of fluconazole, a concentration of up to $97.99 \mu \mathrm{g} / \mathrm{mL}$ can be detected and after $24 \mathrm{~h}$ the bioavailability may be reduced to $2.25-4.52 \mu \mathrm{g} / \mathrm{mL}$ (19). Another important point to highlight is that the half-life of fluconazole ranges from 27 to $37 \mathrm{~h}(20)$, indicating that after administration it can be found in saliva for up to $24 \mathrm{~h}$. In contrast, the concentration of nystatin has a rapid decrease with time after topical administration (21). However, this antifungal agent is capable of eliciting a longer postantifungal effect(PAFE), with the highest values ranging from 0.43 to $21.05 \mathrm{~h}$ (22). Thus, it is important to notice that in the present study was considered a compatible time of exposure and concentrations to those used in clinical practice.

In order to verify the biofilm viability after fluconazole or nystatin exposure, in the present study was evaluated C. albicans biofilm metabolic activity using the XTT colorimetric method $(6,15)$. By this method, the results revealed that both fluconazole and nystatin reduced the metabolic activity of $C$. albicans biofilms, but they were not eradicated at concentrations higher than MIC. For fluconazole, no difference was observed in susceptibility at $10 \mathrm{x}$ MIC or $100 \mathrm{x}$ MIC concentrations, suggesting that $10 \mathrm{x}$ MIC was sufficient to render the biofilm to a dormant stage, which corroborates with other studies $(6,7)$. For nystatin, a great reduction was
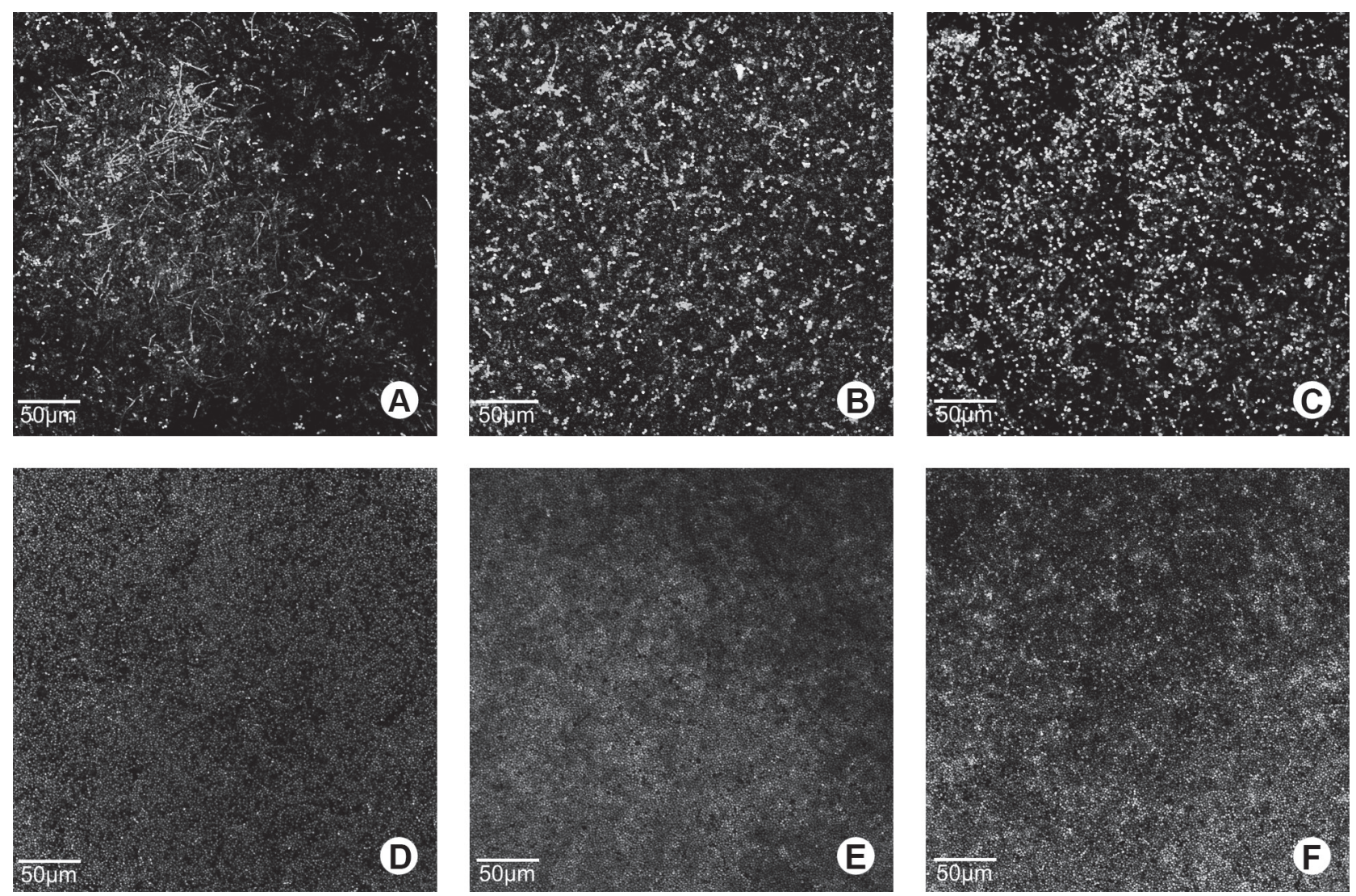

Figure 4. Confocal z-slices images of C. albicans biofilms developed on PMMA surface in the presence of fluconazole (A: MIC, B:10 x MIC and C: 100 x MIC) or nystatin (D: MIC, E: 10 x MIC and F: 100 x MIC). 
observed at $10 \times$ MIC concentration and, possibly, complete biofilm eradication at $100 \mathrm{x}$ MIC concentration. These results are justified by the fungicidal mechanism of action of this drug. Nystatin is capable to intercalate into ergosterol-containing membranes, a component of the fungal membrane, forming channels and destroying the proton gradient in the cell with leakage of cytoplasmic content, resulting in fungal death $(9,21,22)$.

Considering that the biofilm matrix is one of the main components related to the biofilm architecture $(3,4)$, in the present study was evaluated the exopolysaccharide and intracellular polysaccharide of biofilms after exposure to fluconazole or nystatin. For fluconazole, it was observed that the exopolysaccharide matrix was not affected at all tested concentrations. It is possible to speculate that the continuous presence of the drug at the different tested concentrations could stimulate the production of extracellular glucans, which were deposited in the matrix. It is known that these extracellular glucans are important for biofilm resistance and act by sequestering antifungals such as fluconazole, rendering cells resistant to their action and preventing its intracellular penetration (23).

Another important finding was the great amount of intracellular polysaccharide at MIC and 10 x MIC found in the presence of fluconazole, while less intracellular polysaccharide was observed at $100 \mathrm{x}$ MIC. It is known that fluconazole is able to deform the cell nucleus and increase the number of vacuoles (20), which are correlated to the fluconazole mechanism of action, inhibiting the ergosterol biosynthesis (9). With this inhibition, toxic substances that are ergosterol precursors and also polysaccharides could accumulate in the cell, probably in these vacuoles, explaining our results of IP for MIC and $10 \mathrm{x}$ MIC. However, at a concentration higher than $100 \mathrm{x}$ MIC, it is possible to speculate that many cells suffered lyses, resulting in the lower IP values observed.

Considering that one of the assumptions of this study was the possibility of modifying the architecture of developed biofilms after antifungal exposure, it was possible to observe that both drugs did not alter the bio-volume, average thickness and diffusion distance at all the tested concentrations. These findings may be explained, at least in part, by the polysaccharide matrix results. Even reducing metabolic activity and possibly the number of cells, the architectural parameters represented not only the cell volume, but the volume occupied by the matrix and biomass of dead cells. In addition, the small changes could be associated with the time of antifungal exposure, i.e. $24 \mathrm{~h}$, and the fact that the biofilm was already grown when the antifungal therapy was initiated. Additionally, for the percentage of dead/ live cells were observed higher amounts after nystatin exposure as confirmed by the obtained confocal images. This result complements and explains the reduction in metabolic activity, justifying the capacity of nystatin to cause fungal cell death $(9,21,22)$. Although the small changes were defined in the architectural parameters, images obtained by confocal microscopy showed some morphological aspects, such as the presence of black spaces between cells and the hyphal forms after exposure to fluconazole. It is possible to suggest that black spaces may be occupied by exopolysaccharide, which explains the high amount of formed matrix. Additionally, the large number of hyphal forms presented at MIC concentration was also an important finding. It is known that the ability to form hyphae is an important virulence attribute of C. albicans (4). In this context, it is possible that continuous exposure of biofilms to low concentrations of fluconazole stimulated cells dimorphism, which could actually affect secretion of hydrolytic enzymes and thereby increase biofilms pathogenicity $(24,25)$.

Within the limitations of this study, it may be concluded that both fluconazole and nystatin reduced the metabolic activity of C. albicans biofilms; however, they were not able to alter the exopolysaccharide matrix and biofilm architecture.

\section{RESUMO}

Este estudo avaliou o efeito da exposição de fluconazol ou nistatina a biofilmes de Candida albicans desenvolvidos, considerando a matriz de polissacarídeos extracelulares. Inicialmente uma cepa referência de C. albicans (ATCC 90028) foi submetida ao teste de concentração inibitória mínima (CIM) utilizando-se o fluconazol ou nistatina como agentes antifúngicos. Após, espécimes foram confeccionados em resina acrílica de polimetilmetacrilato (PMMA) de acordo com as recomendações do fabricante e tiveram sua rugosidade de superfície padronizada. Após, biofilmes de C. albicans foram desenvolvidos na superfície dos espécimes durante $48 \mathrm{~h}$. Em seguida, os biofilmes foram expostos a fluconazol ou nistatina nas concentrações de CIM, 10 x CIM ou 100 x CIM, por 24 h. A atividade metabólica dos biofilmes foi avaliada pelo teste de XTT. A produção de polissacarídeos extracelulares solúveis e insolúveis, bem como dos polissacarídeos intracelulares foi avaliada pelo método fenol-sulfúrico. A arquitetura dos biofilmes e proporção de células vivas e mortas foi investigada utilizando-se microscopia confocal a laser. Os resultados foram analisados por ANOVA seguido do teste de Tukey, utilizando-se o nível de significância de 5\%. A presença do fluconazol ou nistatina em concentrações maiores que CIM 
resultaram em uma redução significativa da atividade metabólica $(p<0,001)$. Nas concentrações de CIM e 10 x CIM, biofilmes expostos ao fluconazol apresentaram quantidades significativas de polissacarídeos intracelulares $(p<0,05)$, enquanto não houve alterações na quantidade de polissacarídeos extracelulares ( $p>0,05)$. A presença de nistatina também não alterou a matriz de polissacarídeos extracelulares em todas as concentrações investigadas $(p>0,05)$. A arquitetura dos biofilmes não foi afetada por ambos os agentes antifúngicos, em qualquer concentração testada $(\mathrm{p}>0,05)$. A nistatina apresentou maior proporção de células mortas $(p<0,05)$. Conclui-se que tanto para o fluconazol quanto para a nistatina, concentrações maiores que CIM reduziram a atividade metabólica dos biofilmes de C. albicans; no entanto, tais concentrações não alteraram a matriz de polissacarídeos extracelulares nem a arquitetura dos biofilmes.

\section{ACKNOWLEDGEMENTS}

This study was conducted with intramural funds from the OBUHKU. Wander J. da Silva (postgraduate student, PDEE/BEX 4621/06-9) were financially supported by Capes-Brazil.

\section{REFERENCES}

1. Gendreau L, Loewy ZG. Epidemiology and etiology of denture stomatitis. J Prosthodont 2011;20:251-260.

2. Tobudic S, Kratzer C, Lassnigg A, Presterl E. Antifungal susceptibility of Candida albicans in biofilms. Mycoses 2012;55:199-204.

3. Chaffin WL. Candida albicans cell wall proteins. Microbiol Mol Biol Rev 2008;72:495-544.

4. Seneviratne CJ, Jin L, Samaranayake LP. Biofilm lifestyle of Candida: a mini review. Oral Dis 2008;14:582-590.

5. Ramage G, Rajendran R, Sherry L, Williams C. Fungal biofilm resistance. Int J Microbiol 2012;2012:528-521.

6. Chandra J, Kuhn DM, Mukherjee PK, Hoyer LL, McCormick T, Ghannoum MA. Biofilm formation by the fungal pathogen Candida albicans: development, architecture, and drug resistance. J Bacteriol 2001;183:5385-5394.

7. Konopka K, Dorocka-Bobkowska B, Gebremedhin S, Duzgunes N. Susceptibility of Candida biofilms to histatin 5 and fluconazole. Antonie Van Leeuwenhoek 2010;97:413-417.

8. Baillie GS, Douglas LJ. Effect of growth rate on resistance of Candida albicans biofilms to antifungal agents. Antimicrob Agents Chemother 1998;42:1900-1905.

9. Niimi M, Firth NA, Cannon RD. Antifungal drug resistance of oral fungi. Odontology 2010;98:15-25.

10. Ramage G, Mowat E, Jones B, Williams C, Lopez-Ribot J. Our current understanding of fungal biofilms. Crit Rev Microbiol 2009;35:340-355.

11. Baillie GS, Douglas LJ. Matrix polymers of Candida biofilms and their possible role in biofilm resistance to antifungal agents. $\mathrm{J}$ Antimicrob Chemother 2000;46:397-403.

12. Seneviratne CJ, Jin LJ, Samaranayake YH, Samaranayake LP. Cell density and cell aging as factors modulating antifungal resistance of Candida albicans biofilms. Antimicrob Agents Chemother 2008:52:3259-3266.

13. da Silva WJ, Seneviratne J, Samaranayake LP, Del Bel Cury AA. Bioactivity and architecture of Candida albicans biofilms developed on poly (methyl methacrylate) resin surface. J Biomed Mater Res B Appl Biomater 2010;94:149-156.

14. CLSI. Reference method for broth dilution antifungal susceptibility testing of yeasts, approved standard. CLSI Document M27-A3 2008. Wayne, PA:CLSI.

15. da Silva WJ, Seneviratne J, Parahitiyawa N, Rosa EA, Samaranayake LP, Del Bel Cury AA. Improvement of XTT assay performance for studies involving Candida albicans biofilms. Braz Dent J 2008;19:364-369.

16. Tenuta LM, Ricomini Filho AP, Del Bel Cury AA, Cury JA. Effect of sucrose on the selection of mutans streptococci and lactobacilli in dental biofilm formed in situ. Caries Res 2006;40:546-549.

17. Dubois M, Gilles K, Hamilton JK, Rebers PA, Smith F. A colorimetric method for the determination of sugars. Nature 1951;28;168:167.

18. Heydorn A, Nielsen AT, Hentzer M, Sternberg C, Givskov M, Ersboll BK, et al.. Quantification of biofilm structures by the novel computer program COMSTAT. Microbiology 2000;146:23952407.

19. Force RW, Nahata MC. Salivary concentrations of ketoconazole and fluconazole: implications for drug efficacy in oropharyngeal and esophageal candidiasis. Ann Pharmacother 1995;29:10-15.

20. Gomes PN, da Silva WJ, Pousa CC, Narvaes EA, Del Bel Cury AA. Bioactivity and cellular structure of Candida albicans and Candida glabrata biofilms grown in the presence of fluconazole. Arch Oral Biol 2011;56:1274-1281.

21. Ellepola AN, Samaranayake LP. Oral candidal infections and antimycotics. Crit Rev Oral Biol Med 2000;11:172-198.

22. Ellepola AN, Samaranayake LP. The postantifungal effect (PAFE) of antimycotics on oral C. albicans isolates and its impact on candidal adhesion. Oral Dis 1998;4:260-267.

23. Nett JE, Sanchez H, Cain MT, Andes DR. Genetic basis of Candida biofilm resistance due to drug-sequestering matrix glucan. J Infect Dis 2010;202:171-175.

24. Mores AU, Souza RD, Cavalca L, de Paula e Carvalho A, Gursky LC, Rosa RT, et al.. Enhancement of secretory aspartyl protease production in biofilms of Candida albicans exposed to subinhibitory concentrations of fluconazole. Mycoses 2011;54:195201.

25. Goncalves LM, Del Bel Cury AA, Sartoratto A, Garcia Rehder VL, Silva WJ. Effects of undecylenic acid released from denture liner on Candida biofilms. J Dent Res 2012;91:985-989.

Received October 30, 2012 Accepted November 20, 2012 